\title{
Zimbabwean Foodways, Feminisms, and Transforming Nationalisms in Tsitsi Dangarembga's Nervous Conditions and NoViolet Bulawayo's We Need New Names
}

\author{
F. Fiona Moolla \\ University of the Western Cape, South Africa \\ fmoolla@uwc.ac.za
}

\begin{abstract}
Food studies are a productive lens through which to view the impact of social, cultural, historical and political shifts on conceptions of female identity. Nervous Conditions (1988) and We Need New Names (2013) are two novels which link the coming of age of two young women with the development of nationalism, in the first case, and the forced transnationalism of Zimbabwean refugees and exiles in the second. The story of these female and national identity transformations is conveyed, in part, through food-its production, sale, preparation, consumption, and cultural significance. The replacement of sadza and mbodza by the British cuisine of the 196os in the novel of colonialism and national independence is paralleled in the replacement of food scarcity (symbolized by NGo beans, maize, and sugar) with the fast food of American consumer culture, and its impact on the Zimbabwean diaspora in the later novel of transnationalism. The centrality of the cultivation of mealies, which paradoxically both burdens and "liberates" in Nervous Conditions, occurs only as a pastoral backdrop to caricatured indigeneity in We Need New Names. In the later novel, the nutritional and cultural significance of maize is reduced to the mealie meal handed out by NGO workers. Maize's centrality is replaced in We Need New Names by constipation-inducing guavas. But in this novel also, maize finally holds out the symbolic possibility of new senses of belonging and home.
\end{abstract}




\section{Keywords}

food studies - feminism - colonialism - postcolonialism - nationalism - transnationalism - Zimbabwean novel

Indexed by their opening pages, both Tsitsi Dangarembga's oft-prescribed, extensively studied novel Nervous Conditions (1988) and the Man Booker-shortlisted novel We Need New Names (2013) by the Caine Prize-winning author NoViolet Bulawayo foreground the significance of food in the stories that they tell. Food acts as metaphor and symbol, but food is also presented as mutually constitutive of the narrative of personal and national/postnational development which may be detected in these two Zimbabwean novels.

There are thirteen highly significant references to food in the first chapter of Nervous Conditions, which foreshadow the major personal dynamics and transformations upon which the novel expands in the body of the narrative. At the outset, the production, transport, preparation, and serving of food are identified with women, and major cultural transformations are signalled through changes in food consumption. In this bildungsroman, the heroine Tambu's development is conditional upon the death of her brother, Nhamo, which symbolically throws down the feminist gauntlet to conceptions of patriarchy and the inviolability of the African family. As the son of the poor relations, Nhamo is given the opportunity for formal, colonial education by his school-principal uncle, Babamukuru. Returning from the mission school to the homestead where his own family lives, Nhamo is distanced from food, since he despises sharing the bus with "various kinds of produce in suspicious stages of freshness, with frightened hens [and] with the occasional rich-smelling goat." By contrast, women in general, and Tambu in particular, are associated with food right from the start. The food stalls at the bus terminus are all run by women and the walk to and from the terminus affords Tambu the opportunity to chat to neighbours while admiring the "broad-leafed abundance of the maize crop when it was good"2 and the delicious pleasures of wild fruit in the uncultivated areas. Ironically, Nhamo returns home at the end of the school year, which is also the beginning of the maize year, but refuses to get involved in the "uncomfortable tasks of pulling down and stacking the maize and strip-

1 Tsitsi Dangarembga, Nervous Conditions (London: The Women's Press, 1988): 1-2.

2 Dangarembga, Nervous Conditions, 2. 
ping the cobs of their leaves,"3 leaving these tasks to his mother and sisters. The sociability of food production is reflected again in the sociability of food preparation, where Tambu appears to find a measure of self-expression through cooking, after preliminary tasks are shared by the sisters. Animal consumption is presented as an index of times of prosperity, since chicken and goat meat are consumed only on the odd occasions on which these are available. Animal consumption is also presented as a sign of male privilege, linked to the return of male 'heroes' such as Nhamo, who usually has a chicken slaughtered in his honour, and Babamukuru, who is fêted with a goat if there is one. The strenuous physical tasks involved in securing, slaughtering, and preparing the animal for cooking, by contrast, are presented as female labour-something that, interestingly, unlike the production and preparation of vegetables, repels Tambu. The first chapter also proleptically presents an internal change from food as produce to food as consumer good. One sees the infiltration of global consumer culture in the form of the Fanta and Coca-Cola that increasingly come to be sold at the stalls at the bus terminus; and the sugar and tea which Nhamo brings from the mission and reserves for himself. (There is an indirect critique of the globalization represented by the sale of fizzy drinks: the patchy damaged skin of women who use skin lighteners is described later in the novel as being like Fanta and Coca-Cola.) The food-culture transformation represented in germ in the first chapter is explored further in Tambu's subsequent move from the homestead to the mission.

Food dominates the first chapter of We Need New Names in an even more striking way than in Nervous Conditions. More correctly, it is the lack of food, or food scarcity, to which our attention as readers is repeatedly drawn. The novel opens with a group of starving children who, showing the remarkable resilience of the young, turn their deprivation into an opportunity for adventure, ironically refracting the privilege of the children in the classic British adventure novel. The children "hit Budapest," the upmarket suburb near the shanty town of "Paradise" where they live, to steal guavas off the trees in the gardens of the palatial homes:

We are on our way to Budapest: Bastard and Chipo and Godknows and Sbho and Stina and me. We are going even though we are not allowed to cross Mzilikazi Road, even though Bastard is supposed to be watching his little sister Fraction, even though mother would kill me dead if she found out; we are just going. There are guavas to steal in Budapest, and right now

3 Nervous Conditions, 6. 
I'd rather die for guavas. We didn't eat this morning and my stomach feels like somebody just took a shovel and dug everything out. ${ }^{4}$

The novel, here and throughout, cleverly uses a picaresque style of humour to deliver trenchant social critique. For Darling, death by corporal punishmentbeing killed by her mother-is presented as more desirable than death by starvation even though premature death is the eventual, almost inescapable outcome for these children in dictatorship-controlled Zimbabwe, as presented in the novel. Similarly, at the end of the chapter, the children steal the shoes off a female AIDs suicide hanging from a tree to buy "a loaf, or maybe even one and a half" 5 of Lobels bread. (Lobels was the major Zimbabwean bakery, whose demise in 2007 in some ways symbolized Zimbabwe as a 'failed state'.) Macabre humour is underscored by the description of what the children do once they have tugged the shoes off the dangling corpse. Intoxicated by the "dizzying smell of Lobels bread," the children charge off and the protagonist, Darling, reports: "we are rushing, then we are running, then we are running and laughing and laughing and laughing." ${ }^{6}$ Through grotesque humour, the novel thus presents indirect and highly effective social critique. At the end of the novel, too, the macabre is highlighted, since the children are once again intoxicated by the smell of bread from the Lobels truck, impervious to the fact that it has just run over their "pet" stray dog, leaving a gruesome corpse on the road. In the same way as Nervous Conditions foreshadows a transformation in food culture in a nutshell in the first chapter, We Need New Names pre-empts the transformation of food cultures as a consequence of globalization, given material form by Darling's later transnational straddling of the postcolonial Zimbabwean foodway of starvation and the foodway of American overconsumption when she is sent to join her Aunt Fostalina in "Destroyedmichygen."7 Darling's American experience is prefigured by an earlier adventure in Budapest, also presented in the first chapter. Budapest is home to white Zimbabweans and North-Atlantic diasporic Zimbabweans who have returned home. The children encounter in Budapest the 'Afropolitan' daughter of a Zimbabwean who sees the country for the first time at the age of thirty-three. She has matted, messed hair which the children cannot explain, given her obvious affluence. Since she looks emaciated, she poses no threat to the children, who do not run away and instead are fascinated by her interest in them. She takes

\footnotetext{
4 NoViolet Bulawayo, We Need New Names (London: Chatto \& Windus, 2013): 1.

5 NoViolet Bulawayo, We Need New Names, 18.

6 We Need New Names, 18.

7 Bulawayo, We Need New Names, 49 .
} 
photographs of them through the slats of the gate. She eats a slice of salami pizza, which is described in language which makes it clear that pizza is entirely unfamiliar to the children. Even more unthinkably, she tosses the remains of the slice into the outside bin, highlighting the question of food wastage, and later remarks that she has just come off the "Jesus diet," which accounts, in the children's eyes, for her unthreatening, unattractive, and unhealthy skinniness. The problematic relationship with food excess and food wastage embodied in the lifestyle of the transnational elite is developed in fascinating detail later in the novel. In various ways, Nervous Conditions and We Need New Names thus emphasize the 'glocal' ways in which food cultures operate, the colonial/imperial within the local represented by the mission in Nervous Conditions, while Budapest represents the global within the local in We Need New Names.

When one explores the novels, the key points identified in the introductory paragraphs above yield further fascinating insights. While the major journey of the female protagonist in Bulawayo's novel takes place transnationally from Zimbabwe to the USA, the major life-journey in Dangarembga's novel is from the homestead, where Tambu lives with her nuclear family, to the mission, where she lives with her paternal uncle's family. Homestead and mission represent the two poles of a dichotomy, the dynamics of which allow Tambu to recognize herself as a gendered being discriminated against in both locales. The dichotomy is further entrenched by the final move to a prestigious girl's private school, to which Tambu wins admission through a scholarship. In the move from mission to the Young Ladies College of the Sacred Heart, Tambu discovers herself now as a racialized being, while before she recognized only the ways in which she was discriminated against in terms of gender. (It is interesting that in We Need New Names, the later novel of postcolonial dictatorship rather than of colonial oppression, education, by contrast, plays a highly truncated role in the lives of the children described, since formal education systems appear to have collapsed.) The significant transformations entailed by the transfer from homestead to mission for Tambu are transformations which occur also on the level of food. Although food has been indirectly considered in scholarship on this novel through the focus on the alternating anorexia/bulimia ${ }^{8}$ of Nyasha, Tambu's cosmopolitan cousin, who spent her formative years in the colonial centre of London, the sociology and politics of food in the novel have never

8 See, for example, Brendon Nicholls' essay "Indexing Her Digests: Working Through Nervous Conditions," in Emerging Perspectives on Tsitsi Dangarembga: Negotiating the Postcolonial, ed. Anne Elizabeth Willey \& Jeanette Treiber (Trenton NJ: Africa World Press, 2002): 99-134. 
been regarded as significant in their own right. When one begins to focus on food, ideas proliferate seemingly endlessly.

At the homestead, food production, preparation, and serving appear to be the ambiguous burden, and source of independence and power, of women exclusively. Tambu's father, oblivious of colonial societal and economic transformations, uses a food metaphor to condemn Tambu to a peripheral gendered role in a Shona culture disrupted by the impact of colonial forces. Denying her the right to go to school, since her brother Nhamo's education must be privileged because he will be the family breadwinner and she will enter another family through marriage, Tambu's father says to her, "Can you cook books and feed them to your husband?"9 It is food production, a skill taught to Tambu by her grandmother and developed further by her mother, highlighting a line of female influence and network of support through food, that allows Tambu to overcome her father's shortsightedness and unfairness. Tambu grows mealies, the eventual 'sale' of which allows her to fund her own studies. (The novel introduces a curious twist here which would merit further attention in the context of a different essay. Tambu, in fact, gets the money for her studies not from the sale of her produce, but from the prestation of Doris, an elderly white woman, who at first mistakes Tambu for a child co-opted into agricultural forced labour by a ruthless father.) But Tambu is involved in much more than food production. The women at the homestead take full responsibility also for food preparation, a fact made very obvious both by the way in which the transition from homestead to mission is described and from the descriptions of women's work when Babamukuru and family return to the homestead at holidays.

Nervous Conditions is, in a sense, three bildungsromane in one. The novel in the present tells the story of Tambu's education and development from "peasant," as she is described by her cousin Nyasha, to sophisticated woman of the world. The second novel of development is the retrospective narrative of the mature Tambu, looking back at her growth. The third novel of development, and this is a story which is not told, is the narrative of Tambu's 'expansion' of consciousness, referred to in the final paragraph of the novel, which opens up an ironic distance from the first two stories of development. Thus, the move from homestead to mission, which in the 'simple' bildungsroman represents the move from tradition to modernity, in various ways is subjected to irony through the knowing voice of the expanded consciousness. The ironic glance at an uncomplicated idea of development is likewise presented through considerations which open up through foodways. When Tambu first arrives at the

9 Tsiti Dangarembga, Nervous Conditions, 15. 
mission, the kitchen and the dining-room are singled out for detailed description which implicitly contrasts them with the kitchen at the homestead, and involve the social and cultural ways in which meals are eaten. The young Tambu is overly impressed by the antiseptic cleanliness, the running water, and the electric cooker, which she imagines will liberate her from the backbreaking labour of the homestead, where water had to be carried in drums on the head and firewood collected for the smoky, asphyxiating kitchen woodfire. The mission and, by implication, modernity are linked in the mind of the young Tambu with an emancipation of the female body facilitated by modern conveniences. Similarly, the dining-room stands in stark contrast to serving arrangements at the homestead, where men were served the choicest morsels first and women ate out of collective dishes in the smoky kitchen later. The bourgeois middleclass 'architecture' of the dining-room at the mission emphasizes opulence and individualization through the seating and dining arrangements, with personal chairs, crockery, and cutlery. The contrasts between the foodways of tradition and modernity reach a symbolic apex at Tambu's first dinner at the mission, where she has to abandon eating British-style with a knife and fork in favour of spooning sadza from a bowl, since she copes so badly with the colonial markers of dining sophistication. (The link between the conventions of cutlery use and class, modernity and sophistication, is a significant question in We Need New Names as well.) On her first introduction to the kitchen at the mission, furthermore, she encounters Nyasha baking a cake for her brother, Chido, and the kitchen as the preserve of the women at the mission is subsequently reinforced by the fact that men are never associated with that domain. On her first day at the mission, Tambu is treated to an excess of confectionery at tea-time, which so astonishes her that, in her confusion, she ends up taking only one dry biscuit with her tea. The themes of female emancipation from the labours of sustenance, and food in excess, linked with the modernity of the mission, are expanded when Tambu discovers that food takes the form, for the most part, of partly prepared, cleaned consumer goods available in abundance from the shops rather than in the form of produce sown, watered, tended, and harvested, plentiful or scarce depending on many variable factors. In terms of the first simple narrative of gynocentric development, the modernity of the mission is clearly associated with female liberation. Although women rather than men continue to be linked with food at the mission, women are freed from most of the burdensome aspects of food production, preparation, and serving.

But the irony that proliferates through the novel also refracts the idea of women's emancipation from the hard labour of food provision at the mission. The idea of female liberation is undermined by the fact of a consequent loss of independence and power enjoyed by women. At the homestead, women, 
through their sale of fresh produce like maize and eggs, enjoyed a degree of autonomy which they seem to forsake at the mission, where Tambu's aunt, Maiguru, has to wait for her food allowance and a lift to the shops from Babamukuru. Despite the fact that they are modern and educated, both Nyasha and the aunt, Maiguru, lead far more constrained lives than the women at the homestead. Also, in the context of the mission, Nyasha could not conceivably contemplate the successful defiance of her father that Tambu achieved by growing mealies, resisting his attempt to cut short her education. In the modern context, Nyasha's resistance takes the form of a rejection of food, rather than the more positive production of food undertaken by Tambu. Nyasha's anorexia/bulimia, furthermore, is an internal and ultimately destructive conflict which sees her experiencing a nervous collapse at the end. Similarly, the food security apparently guaranteed by modern food production and distribution techniques is warped into an ill-considered display of excess. Excessive food consumption at the mission is highlighted, in particular through the ritual of the dinner-time feeding of Babamukuru on Tambu's first arrival, along with the over-determined listing of the various cakes and biscuits Tambu is offered at her first tea. Many scholars identify the origins of the patriarchal resistance and eventual nervous collapse of Nyasha in the dinner-table agonistics of father and daughter. But Ngũgĩ wa Thiong'o also identifies in the figure of Babamukuru a colonial replica of Victorian patriarchy and capitalist patterns of over-consumption, grotesquely presented:

The greed is very well captured in one of the most terrifying scenes in the narrative: this is the scene [...] in which the women feed him. He literally swallows dish after dish while the entire family watches him gorge himself to near sickness. He eats almost ten times more than he needs which of course means that he is eating food that could have fed more people. His food is snatched from the mouths of the hungry, his water from the mouths of the thirsty, symbolized in this instance by the women and the children around him. ${ }^{10}$

The journey, which is an inescapable motif of the novel of development, is represented in We Need New Names by the move of the central character,

10 Ngũgĩ wa Thiong'o, "Writing a National Agender: Patriarchy as Domestic Colonialism in Tsitsi Dangarembga's Nervous Conditions," in Ngũgĩ wa Thiong'o, In the Name of the Mother: Reflections on Writers \& Empire (Nairobi: East African Educational Publishers \& Woodbridge: James Currey, 2013): 129. 
Darling, from the collapsed postcolonial state ofZimbabwe in the early-twentyfirst century to the USA. Viewed through the lens of food, the journey is one from a diet of no food to a diet of excessive quantities of food. The only references to food eaten by the locals in the Zimbabwean section of the novel are the highly symbolic guavas which recur through the narrative, the Lobels bread which is purchased from the sale of the shoes of the suicide, and the small packets of beans, sugar, and mealie-meal handed out by foreign NGO workers. Paradoxically, the stolen bull guavas, abundant and delicious, cause the children constipation, which sees them squatting in pain in the bushes. That something is really rotten in the state of Zimbabwe is thus apparent from the fact that even the food that is available has no nutritional benefit and results not in the children's healthy growth but in stunted development indicated by constipation. In the American section of the novel, by contrast, the protagonist, Darling, is surrounded by a hitherto unknown excess and variety of food; nevertheless, she remains starved:

there is food to eat here, all types and types of food. There are times though that no matter how much I eat, I find the food does nothing for me, like I am hungry for my country and nothing is going to fix that. ${ }^{11}$

This passage links American food both with poor nutrition and with a loss of national identity. The linking of mass-produced, preservative-laden genetically modified food with poor nutrition and health is highlighted through the many other references in the narrative to the 'globesity' associated with the McDonaldization of the American gastronomic landscape and its expansion through globalization into the rest of the world. (Benjamin N. Lawrance and Caroline de la Peña caution against the "seductive McDonaldization of Everything narrative,"12 which simplifies the complex exchanges and challenges of food globalization, but certainly the effects of McDonald's food culture seems to be accurately described in the American context in We Need New Names.) Excessive food consumption, captured in the McDonald's policy of encouraging 'supersizing', is linked in the novel with obesity and its spin-off-the

11 NoViolet Bulawayo, We Need New Names, 153.

12 Benjamin N. Lawrance \& Caroline de la Peña, "Foodways, 'Foodism,' or Foodscapes? Navigating the Local/Global and Food/Culture Divides," in Local Foods Meet Global Foodways: Tasting History, ed. Lawrance \& de la Peña (Abingdon \& New York: Routledge, 2012): 10. 
obsession with dieting. The novel contrasts the healthy, attractive fat admired in African culture (153) with the unhealthy fat of fast-food cultures when Darling attends the wedding of Dumi, Aunt Fostalina's former beau, to an obese white woman:

In America, the fatness is not the fatness I was used to at home. Over there, the fatness was of bigness, just ordinary fatness you could understand because it meant the person ate well, fatness you could even envy. It was fatness that did not interfere with the body; a neck was still a neck, a stomach a stomach, an arm an arm, a buttock a buttock. But this American fatness takes it to a whole 'nother level: the body is turned into something else- the neck becomes a thigh, the stomach becomes an anthill, an arm a thing, a buttock a I don't even know what. ${ }^{13}$

Debilitatingly, Aunt Fostalina, who is neither African big nor American fat, is obsessed with diets and exercise. This toxic relationship with food is brought into relief by Darling when she observes that Fostalina looks like her father on his return from South Africa to Zimbabwe when he was dying of AIDs: "Aunt Fostalina is thin and very soon she will begin to look like Father's bones, drowning there on the bed and just waiting to die."14 Even though Nervous Conditions is set in the earlier period of nationalism, rather than in the transnationalism associated with postcolonial dictatorship, the earlier novel presciently also figures this dimension of transformation of food cultures. Tambu's feisty aunt, Lucia, represents the ideal of attractive African bigness. Babamukuru represents the obesity linked with capitalist over-consumption, although this is not further explored through decriptions of his body shape, and Nyasha represents the troubled, diet-obsessed modern female aesthetic ideal of angles rather than curves.

The linking of food with identity and belonging is reinforced by the presence of the Ghanaian Kojo, with whom Darling's Aunt Fostalina lives. Although Fostalina keeps the fridge well stocked with ready microwave meals, his hunger is never satisfied until she begins cooking Ghanaian cuisine from scratch. The pattern observed in Fostalina's behaviour, where she appears not to have the time to cook, is a familiar one in Western culture, as the editors of the Routledge Handbook of Sustainable Food and Gastronomy highlight:

\footnotetext{
13 Bulawayo, We Need New Names, 171.

14 NoViolet Bulawayo, We Need New Names, 155.
} 
Despite our obsession with food, Western households seem to be losing the skills their grandmothers held dear. In an age of specialization, preparing food is perceived as time-consuming and requiring years of training. ${ }^{15}$

Similarly, the strongest moments of identification in the text are linked with ample, shared Zimbabwean meals.

The uncles and aunts bring goat insides and cook ezangaphakathi and sadza and mbhida and occasionally they will bring amacimbi, which is my number one favorite relish, umfushwa and other foods from home, and people descend on the food like they haven't eaten all their lives. They tear off the sthwala with their bare hands, hastily roll and dip it in relish and pause briefly to look at one another before shoving it in their mouths. Then they carefully chew, tilting their heads to the side as if the food speaks and they are listening to the taste, and then their faces light up. When they cook home food, even Aunt Fostalina will forget she is on a fruit diet. ${ }^{16}$

Ironically, of course, the sociable pleasures of the meal, the food itself, and the establishment of social and cultural identity through food may be obtained in a foreign country, here the USA, as they are unlikely to do in the home country of Zimbabwe as a consequence of food-scarcity (through mismanagement resulting from inverse racism, corruption, and ignorance), poverty, and rampant inflation. So, through food, the USA, for the diasporic Zimbabwean, is more like home than Zimbabwe. I think that food here is forcing a realization about identity, belonging, and ideas of home which may be specific to the nature of food and the cuisines they support rather than being dependent on artificially created national borders.

Considered through a feminist lens, as compared with the women at the homestead in the nationalist moment of subject-formation, in the transnationalist moment lived by Aunt Fostalina, women would appear to be entirely liberated from the oppression of food-related labour. The passage below brings together Fostalina, her partner, Kojo, and her son "Fat boy тк," whose theme song appears to be the repeated "nting" signal the microwave makes after heat-

\footnotetext{
15 Philip Sloan, Willy Legrand \& Clare Hindley, "Editorial introduction" to The Routledge Handbook of Sustainable Food and Gastronomy, ed. Sloan, Legrand \& Hindley (Abingdon \& New York: Routledge, 2016): xv.

16 Bulawayo, We Need New Names, 161.
} 
ing his many ready meals. The physical emancipation from labour foreshadowed by the mission in Nervous Conditions is fully realized in We Need New Names in this passage:

Uncle Kojo comes home from work and says to Aunt Fostalina, You know, me, I actually don't understand why there is never any hot food in this house, Fostalina. Aunt Fostalina looks up from squeezing an orange and says, No food in this house, Kojo, really? But I just did groceries yesterday, what do you think that fridge over there is full of, huh, bricks? And he says, Fostalina, ever since you started this weight thing you never cook. When was the last time we had a real dinner in this house, heh? You know in my country, wives actually cook hot meals every day for their husbands and children. And not only that, they actually also do laundry and iron and keep the house clean and everything.

Fat boy TK pulls up his trousers and mutters, Patriarchal motherfucker, and Aunt Fostalina throws the rest of the orange in the bin and says, Yes, in your country maybe, but this is America, ... ${ }^{17}$

Paradoxically, virtually complete emancipation from the labours of producing, preparing, and serving food is nevertheless accompanied by the gendered social oppression of unrealistic physical ideals of female beauty that assumed pathological dimensions in the fate of the somewhat less transnational Nyasha in Nervous Conditions.

The final word should, however, be reserved for that archetypally African food, maize, which has enormous symbolic significance in both novels, albeit through its lack in We Need New Names. The cultivation of 'mealies', as maize is referred to in Southern Africa, grants Tambu access to the ambiguous and contradictory rewards of colonial modernity through colonial education. Maize in We Need New Names is a product which comes in a little packet, the cultivation of which is memorialized in family photographs described in unsettling terms, almost as a caricature of lost indigeneity: Darling comes across a hidden picture of her grandfather, whose spirit, it is believed, possesses her, since he was not appropriately laid to rest, because the "white people killed him during the war for feeding and hiding the terrorists." ${ }^{18}$ Darling observes, of her grandfather in the photograph: "He has a bone going through his nose

\footnotetext{
17 NoViolet Bulawayo, We Need New Names, 155-156.

18 NoViolet Bulawayo, We Need New Names, 20. Alluded to here is the 1890 s war of liberation from the British, called the First Chimurenga.
} 
and is wearing earrings. Behind him are fields of waist-high maize crops, just endless and endless green."19 The maize fields of peasant production are contrasted with the maize fields of capitalist agriculture in the USA when Darling travels by car through the American countryside with her Aunt and Uncle Kojo to a wedding. Although Darling laments the fact that American corn is nothing like Zimbabwean mealies, maize nevertheless acts as a marker of home in a new locale established through food. Archetypally African maize is actually indigenous to South America and was brought to Africa as late as the 1500 as a spin-off from the 'Colombian exchange', of which the African slave trade was a part. ${ }^{20}$ Maize is central to the narrative of national independence presented in Nervous Conditions and is the catalyst for the personal development of the heroine, Tambu. In We Need New Names, by contrast, maize and its cultivation are presented as part of a lost past in the Zimbabwe of the novel. However, the novel also makes a link, established through maize, between Africa and the Americas, recollecting the Colombian exchange. Although guavas are the most potent symbol of the ambiguous anti-pastoral of Darling's lost Zimbabwean childhood, underscored by her nostalgia when she gets guavas posted to her in America, it is maize which, I think, represents the food that lightens Darling's life-journey. Through a complex series of transnational exchanges of food and people in a politically dismembered world, the novel suggests, through maize as fraught symbol, the necessity for new names, new locations, and new senses of home and belonging.

\section{Works Cited}

Bulawayo, NoViolet. We Need New Names (London: Chatto \& Windus, 2013). Dangarembga, Tsitsi. Nervous Conditions (London: The Women's Press, 1988).

Lawrance, Benjamin N., \& Caroline de la Peña. 'Foodways, 'Foodism,' or Foodscapes? Navigating the Local/Global and Food/Culture Divides," in Local Foods Meet Global Foodways: Tasting History, ed. Lawrance \& de la Peña (Abingdon \& New York: Routledge, 2012): 2-14.

19 NoViolet Bulawayo, We Need New Names, 24.

20 See James C. McCann, "Naming the Stranger: Maize's Journey to Africa," in McCann, Maize and Grace: Africa's Encounter with a New World Crop, 1500-200o (Cambridge MA: Harvard UP, 2005): $23-38$, for a detailed account of the introduction of maize to Africa from the Americas. 
McCann, James C. "Naming the Stranger: Maize's Journey to Africa," in McCann, Maize and Grace: Africa's Encounter with a New World Crop, 1500-200o (Cambridge MA: Harvard U P, 2005): 23-38.

Ngũgĩ wa Thiong'o. "Writing a National Agender: Patriarchy as Domestic Colonialism in Tsitsi Dangarembga's Nervous Conditions," in Ngũgĩ wa Thiong'o, In the Name of the Mother: Reflections on Writers \& Empire (Nairobi: East African Educational Publishers \& Woodbridge: James Currey, 2013): 118-138.

Nicholls, Brendon. "Indexing Her Digests: Working Through Nervous Conditions," in Emerging Perspectives on Tsitsi Dangarembga: Negotiating the Postcolonial, ed. Anne Elizabeth Willey \& Jeanette Treiber (Trenton NJ: Africa World Press, 2002): 99-134.

Sloan, Philip, Willy Legrand \& Clare Hindley. "Editorial introduction" to The Routledge Handbook of Sustainable Food and Gastronomy, ed. Sloan, Legrand \& Hindley (Abingdon \& New York: Routledge, 2016): xiv-xvi. 